\title{
Antimicrobial Activities of Some Marine Macroalgae Species from Iskenderun Bay
}

\author{
Selin Sayın ${ }^{1, a, *}$ \\ ${ }^{1}$ Department of Marine Technologies, Faculty of Marine Sciences and Technology, Iskenderun Technical University, 31200 Iskenderun, \\ Hatay, Turkey \\ *Corresponding author \\ A R T I C L I N F O A B S T R A C T \\ Research Article \\ In the present study, the seaweeds belong to Phaeophyaceae (Halopteris scoparia (Linnaeus) \\ Sauvageau 1904, Cystoseria mediterranea Sauvageau 1912), Rhodophaceae (Liagora viscida \\ (Forsskål) C.Agardh 1822, Laurencia nidifica J.Agardh 1852) and Chlorophyceae (Enteromorpha \\ multiramosa Bliding, nom. inval. 1960) collected from nearby Iskenderun-Turkey of Mediterranean \\ Sea were detected for their antimicrobial activities against seven bacterial (Escherichia coli ATCC \\ 35218, Bacillus cereus NRRL B-371, Staphylococcus aureus ATCC 25923, Pseudomonas \\ aeruginosa ATCC 27853, Klebsiella pneumoniae ATCC 13883, Salmonella typhimurium ATCC \\ 14028, Proteus vulgaris RSKK 96029) and three fungal strains (Candida albicans ATCC 10231, \\ C. krusei ATCC 6258, C. tropicalis Y-12968). The antimicrobial activities were expressed as \\ minimum inhibitory concentrations (MICs), minimum bacterial concentrations (MBCs) and \\ minimum fungicidal concentrations (MFCs) were determined. According to the results obtained \\ from MIC values of the extracts on pathogenic microorganisms were between 50 and $<0.39 \mathrm{mg} /$ \\ $\mathrm{mL}$, while MBCs/MFCs values were ranged from $>50$ and $<0.39 \mathrm{mg} / \mathrm{mL}$. These results suggest \\ that brown, red, green algae secondary metabolites are important sources that could be used as broad \\ spectrum of biological activities. \\ Keywords: \\ Seaweeds \\ Antimicrobial activities \\ MICs \\ Secondary metabolities \\ Algal extracts
}

elin.sayin@iste.edu.t

(iD) https://orcid.org/0000-0002-7497-388X

This work is licensed under Creative Commons Attribution 4.0 International License

\section{Introduction}

Seaweeds belong to primary producers in aquatic ecosystems a group of plants known as macroalgae and unique biological activities. Seaweeds are classified into three broad groups based on their nutrient and chemical composition; brown (Phaeophyta), red (Rhodophyta), or green (Chlorophyta) algae. Like other plants, seaweeds reveals that these natural biological active compounds in algae are an important resource for human health (Kuda et al., 2002). Seaweeds are defined as the main source of bioactive components that have the ability to produce a large variety of secondary metabolites distinguished by a wide range of natural biological activities.

Seaweeds are very rich in protein, carbohydrate, lipid, pigments, amino acids, fatty acids and glycerol, and also contain bioactive substances with antiviral, antifungal and antibacterial properties such as polyphenols and polysaccharides, vitamins and minerals. Secondary metabolites as essential oils, alginic acid, agar, carrageenan, organic acids, cellulose, alkaloid, sterol, phenolic and many other substances extracted from structural materials in algae cells or cell walls (Mohammed et al., 2018; Mohammed et al., 2020). Because of these properties, seaweeds are used in many areas such as medical, pharmaceutical, microbiology, biotechnology and food, cosmetics, animal feed, fertilizer industries (Watson et al., 2003; Yuan et al., 2005; Bansemir et al., 2006; Chew et al., 2008). Various studies have been reported that seaweeds used in several implementations such as antioxidant (Devi et al., 2011), antimicrobial (Chiheb et al., 2011), antiviral (Bouhlal et al., 2011), antifungal (De Felicio et al., 2010), antibiotic (Chew et al., 2008), antiinflammatory (Moshfegh et al., 2019), antiallergic (Na et al., 2005), antitumoral and anticancer (Kim et al., 2011; Martins et al., 2018) and antifouling (Bhadury and Wright, 2004) anticoagulant activities (Dayong et al., 2008).

As a consequence of an increasing demand in screening for research on the use of algae as pharmacological and nutraceutical agents from natural products, there is more 
interest in aquatic organisms in research on this issue. Many seaweed species with bioactive compounds have been shown to inhibit the growth of some gram-negative and gram-positive bacterial pathogens and identified as potential a source of natural antioxidants (Matanjun et al., 2008). Several researchers investigated the antimicrobial potential of seaweeds detected in different regions of our country (Battu et al., 2011, Tuney et al., 2006). Harder (1917) was pioneer of studies detecting the antimicrobial activities of seaweeds. Antibacterial compounds identified in seaweeds have been shown to have bactericidal agents as alkaloids, aminoacids, fatty acids, acrylic acid, terpenoids, phlorotannins, oil, lipophilic compound, phenolics, steroids, polyphenols, halogenates and isopyrenoid compounds (Glombitza, 1979; Watson and Cruz-Rivera, 2003; Paul and Puglisi, 2004). In the present study, we report that the effect of brown, red and green macroalgae collected from the Iskenderun Bay against pathogens.

\section{Materials and Methods}

\section{Macroalgae Species}

Macroalgae species of Halopteris scoparia (Linnaeus) Sauvageau 1904, Cystoseria mediterranea Sauvageau 1912, Liagora viscida (Forsskål) C.Agardh 1822, Laurencia nidifica J.Agardh 1852) and Enteromorpha multiramosa Bliding, nom. inval. 1960 were collected nearby Iskenderun-Turkey of Mediterranean Sea. Macroalgae were washed with distilled water and dried under room temperature.

\section{Microorganisms and Growth Conditions}

Seven bacterial and three fungal strains have been used to detect the antimicrobial activities of the extracts. Bacterial strains were as follows; Escherichia coli ATCC 35218, Bacillus cereus NRRL B-371, Staphylococcus aureus ATCC 25923, Pseudomonas aeruginosa ATCC 27853, Klebsiella pneumoniae ATCC 13883, Salmonella typhimurium ATCC 14028, Proteus vulgaris RSKK 96029; and fungal strains were Candida albicans ATCC 10231, C. krusei ATCC 6258, C. tropicalis Y-12968.

\section{Preparation of Algal Extracts for Antimicrobial Activity}

All of the extracts were prepared in DMSO at a concentration of $250 \mathrm{mg} / \mathrm{mL}$ and sterilized by a $0.45 \mathrm{~mm}$ pore sized syringe filter.

\section{Broth Microdilution Assay}

The minimum inhibitory concentrations (MIC) of the extracts were evaluated by the broth microdilution assay in 96-well microtitre plates according to CLSI reference methods for bacteria M7-A7 (CLSI, 2018) and yeasts M27A3(CLSI, 2008). $100 \mu \mathrm{L}$ of the medium (Mueller Hinton broth for bacteria, Saboroud Dextrose broth for fungi) was added to each well for antimicrobial testing. At first well, $250 \mathrm{mg} / \mathrm{mL}$ of extract solution was added and then twofold serial dilutions were made at a concentration range of 250-0.98 mg / mL on 96-well microtitre plate in Mueller Hinton broth for bacteria or Saboroud Dextrose broth for fungi. Antibiotics used as positive controls include ampicillin, chloramphenicol and ketoconazole (Sigma). Microorganism inoculums were prepared from a 24-hour culture and suspensions in $0.9 \%$ of $\mathrm{NaCl}$ were adjusted to 0.5 McFarland standard turbidity. Five microliters of microorganisms have been added to all wells. The microtitre plates were then incubated bacterial strains for $24 \mathrm{~h}$ at $37^{\circ} \mathrm{C}$ and fungal strains for $48 \mathrm{~h}$ at $30^{\circ} \mathrm{C}$. After incubation, MICs of the extracts were obtained by lack of visual turbidity. The minimum bacterial concentration (MBC) and minimum fungicidal concentration (MFC) of the were detected by subculturing ten microliters volumes from non-turbid wells and spot inoculating onto an appropriate growth medium. After incubation, growth was reported and $\mathrm{MBCs} / \mathrm{MFC}$ s were defined as the lowest concentration resulting in the death of $99.9 \%$ of the inoculum compared to the initial valid counts. The assay was recurrent at least three times and the characteristic values of MIC and MBC / MFC were selected.

\section{Results and Discussion}

Many natural resources in natural ecosystems have antimicrobial properties (Sevindik, et al., 2017; Sevindik, 2020). In this study we conducted, the antimicrobial potentials of macroalgae were determined. Extracts of macroalgae species (H. scoparia, L. viscida, $E$. multiramosa, C. mediterranea, L. nidifica) were tested against seven bacteria (E. coli, B. cereus, S. aureus, $P$. aeruginosa, K. pneumoniae, S. typhimurium, $P$. vulgaris) and three fungal strains $(C$. albicans, $C$. krusei, $C$. tropicalis). MICs values of the the extracts of macroalgae species possessed antimicrobial activity were summarized in Table 1. The minimum bacterial (MBCs) and minimum fungicidal concentration (MFCs) values of the extracts of macroalgae species were presented in Table 2.

Table 1. Minimum inhibitory concentration (MICs) values of the macroalgae species extracts

\begin{tabular}{l|ccccccc}
\hline \multicolumn{1}{c}{ Species } & $\begin{array}{c}\text { E. coli } \\
\text { ATCC 35218 }\end{array}$ & B. cereus & S. aureus & P. aeruginosa & K. pneumoniae & S. typhimurium & P. vulgaris \\
\hline H. scoparia & 25 & 6.25 & 12.5 & 12.5 & 25 & 50 & 25 \\
L. viscida & 62.5 & $<0.98$ & 3.91 & 31.25 & 31.25 & 31.25 & 31.25 \\
E. multiramosa & 25 & $<0.39$ & 1.56 & 12.5 & 12.5 & 50 & 25 \\
C. mediterranea & 15.63 & 15.63 & $<0.98$ & 15.63 & 7.81 & 15.63 & 3.91 \\
L. nidifica & 31.25 & $<0.98$ & 3.91 & 31.25 & 31.25 & 31.25 & 62.5 \\
Ampicillin & $>125$ & 31.25 & 62.5 & $>125$ & 125 & 62.5 & $>125$ \\
Chloramphenicol & $>125$ & 125 & 125 & $>125$ & 15.63 & 125 & 125 \\
\hline
\end{tabular}


Table 2. Minimum bacterial concentration (MFC) values of the macroalgae species extracts

\begin{tabular}{|c|c|c|c|c|c|c|c|}
\hline Species & $\begin{array}{c}\text { E. coli } \\
\text { ATCC } 35218\end{array}$ & B. cereus & S. aureus & P. aeruginosa & K. pneumoniae $S$ & S. typhimurium & n P. vulgaris \\
\hline H. scoparia & 50 & $>50$ & 12.5 & 12.5 & 25 & 50 & 25 \\
\hline L. viscida & 125 & $<0.98$ & 15.63 & 62.5 & 125 & 125 & 62.5 \\
\hline E. multiramosa & 25 & $<0.39$ & 6.25 & 12.5 & 12.5 & 50 & 25 \\
\hline C. mediterranea & 15.63 & 15.63 & 7.81 & 15.63 & 15.63 & 15.63 & 3.91 \\
\hline L. nidifica & 125 & $<0.98$ & 15.63 & 62.5 & 125 & 125 & 62.5 \\
\hline Ampicillin & $>125$ & $>125$ & 62.5 & $>125$ & 125 & 62.5 & $>125$ \\
\hline Chloramphenicol & $>125$ & 125 & $>125$ & $>125$ & 15.63 & 125 & $>125$ \\
\hline
\end{tabular}

According to the results obtained from the present study, MICs values of the extracts on pathogenic microorganisms were between 50 and $<0.39 \mathrm{mg} / \mathrm{mL}$ (Table 1), while MBCs / MFCs values were ranged from $>$ 50 and $<0.39 \mathrm{mg} / \mathrm{mL}$. Also, the most effective extract on bacteria was E. multiramosa extract with the lowest MICs and MBCs $(<0.39 \mathrm{mg} / \mathrm{mL}$ ) on B. cereus (Table 2). Besides, this value was even lower than that of ampicillin and Chloramphenicol antibiotics used as positive controls.

In addition, all extracts used in the study had better antimicrobial effects on E. coli ATCC 35218, B. cereus, $S$. aureus, $P$. aeruginosa, $S$. typhimurium and $P$. vulgaris than ampicillin and chloramphenicol antibiotics. Other species except $C$. mediterranea showed the highest effect on $B$. cereus. On the contrary, the least effect was observed on $S$. typhimurium bacteria.

Dulger et al. (2009) have shown that the methanolic extracts of $H$. scoparia inhibits S. aureus, E. coli, $P$. aeruginosa and have antifungus activity on Candida $s p$. and Kluyveromyces fragilis. Febles et al (1995) have found that ethanol extracts of $H$. scoparia that collected in winter and autumn have antibacterial activity against $B$. cereus an B. subtilis and have no antimicrobial activity on $S$. aureus. Although, methanol extracts of $H$. scoparia inhibits $S$. aureus in winter and autumn.

Tuney et al. (2006) have demonstrated that the diethyl ether extracts of $C$. mediterranea have antimicrobial activity against E. coli, E. faecalis and P. aeruginosa and have antifungus activity against Candida $s p$.

Vairappan et al. (2001) have shown that halogenated metabolites and their antibacterial potential of the isolated of Okinawan Laurencia sp. were tested against eight species of marine bacteria the results have demonstrated that Laurencia sp. inhibits Alcaligenes aquamarinus, Azomonas agilis, Azotobacter beijerinckii, Erwinia amylovora, and E. coli. Salvador et al. (2007) tested $L$. viscida aganist B. subtilis, B. cereus, S. aureus, E. coli and $P$. aeruginosa and it has not shown antibacterial activity.

As Tables 1 and 2 presented, all extracts have antimicrobial effects against the tested macroalgae species. The extracts performed a higher antimicrobial activity than antifungal activity. Among the seaweed species used in this study, C. mediterranea, L. viscida, L. nidifica have been determined antimicrobial activity against both bacteria and fungi. In previous study, researchers the antimicrobial activity of the seaweeds in Turkey which were to evaluated. They determined that among the seaweed species used in this study, $C$. compressa have shown an excellent antimicrobial activity against both bacteria and fungi (Dulger et al., 2009). In another study, Salvador et al. (2007) reported that 82 different marine macroalgae classified the Chlorophyceae, Phaeophyceae, and Rhodophyceae investigated for antimicrobial activity. Among the selected taxa of brown algae as known Phaeophyceae were determined that the most effective antimicrobial activity.

The high activity of the MICs and MBCs of macroalgae extracts against bacteria and fungi which were identified in the present study, are consistent with the results of MICs and MBCs / MFCs that were previously reported in other studies (Lambert et al., 2001; Stirk et al., 2007; El-Baky et al., 2009; Ertürk and Taş, 2011; Salem et al., 2011; Hernandes et al., 2013; Venugopa et al., 2014; Al-Judaibi et al., 2014; Zahrani et al., 2014; Veeramohan et al., 2017; Srikong et al., 2017; Martins et al. 2018; Erdogan Eliuz et al., 2019; El-Sheekh et al.,2020).

Pesando (1990) reported that all types of antimicrobial metabolites including (green, brown red algae) exist in temperate or tropical marine. In this study, significant levels of antimicrobial effects were observed in macroalgae extracts. Similar results were also obtained by Kandhasamy and Arunachalam (2008) and Karthikaidevi et al. (2009).

Previous studies reported that red, brown and green macroalga extracts showed antimicrobial properties against various microorganisms and this antimicrobial activity was found in macroalgae extracts due to the presence of bioactive compounds also known as secondary metabolites. Secondary metabolites that differ regarding their species are defined as molecules those are responsible for antimicrobial activity (Bourgougnon and Stiger Pouvreau, 2012, Mohammed et al., 2018; Mohammed et al., 2020). Studies previously reported that chemical composition and antimicrobial activity of macroalgae vary depending on different species, the region where the thalli are located, physiological and environmental (climate, region, salinity, temperature) conditions, pollution, growth conditions, harvest time and epiphytic organisms (Nagayama et al., 2002; Demirel et al., 2009; Alghazeer et al., 2013; Parsaeimehr and Lutzu, 2016; Sevindik et al., 2017; Gümüş et al., 2018; Güner et al., 2019; Moshfegh et al., 2019; Sevindik 2020; Wang et al., 2020).

\section{Conclusion}

Macroalgae have been commonly used in food, medicine, pharmacy, cosmetics and other industrial fields for a long time because they contain bioactive components. On the other hand, the antimicrobial capacity of macroalgae extract depends on different variables such as macroalgae type, solvent, extraction method, extract concentration and the type of the microorganisms used. As 
a result; the influences of the antimicrobial extract, which exists in macroalgae, may replace among natural protective antimicrobial agents in different areas of the industry with the aid of further detailed studies.

\section{References}

Alghazeer R, Whida F, Abduelrhman E, Gammoudi F, Azwai, S. 2013. Screening of antibacterial activity in marine green, red and brown macroalgae from the western coast of Libya. Natural Science, 5(1): 7-14

Al-Judaibi A. 2014. Antibacterial Effects of Extracts of Two Types of Red Sea Algae. Journal of Biosciences and Medicines, 2: 74-82.

Al-Zahrani A, Al-Haj N, Omer H, Al-Judaibi A. 2014. Impact of Extracts of Marine Macroalgae on Multidrug-Resistant Bacteria. Journal of Microbiology Research, 4: 18-24.

Bansemir A, Blume M, Schroder S, Lindequist U. 2006. Screening of cultivated seaweeds for antibacterial activity against fish pathogenic bacteria. Aquaculture, 252:79-84.

Battu GR, Ethadi S, Prayaga Murthy P, Praneeth VS, Rao M. 2011. In vitro antibacterial activity and preliminary phytochemical screening of three algae from Visakhapatnam Coast, Andhra Pradesh, Indian International Journal of Pharmaceutical Sciences, 3 (4): 399-401.

Bhadury P, Wright CP. 2004. Exploitation of marine algae: biogenic compounds for potential antifouling application. Planta, 219: 561-578.

Bouhlal R, Haslin C, Chermann JC, Colliec Jouault S, Sinquin C, Simon G, Cerantola S, Riadi H, Bourgougnon N. 2011. Antiviral activities of sulfated Polysaccharides isolated from Sphaerococcus coronopifolius (Rhodophyta, Gigartinales) and Boergeseniella thuyoides (Rhodophyta, Ceramiales). Marine Drugs, 9: 1187-1209.

Bourgougnon N, Stiger-Pouvreau V. 2012. Chemodiversity and bioactivity within red and brown macroalgae along the French coasts, metropole and overseas departements and territories. 58-105 pp. In: Kim, S-K. (Eds.), Handbook of Marine Macroalgae. JohnWiley \& Sons, Ltd., 567 p.

Chew YL, Lim YY, Omar M, Khoo KS. 2008. Antioxidant activity of three edible seaweeds from two areas in South East Asia. Lebensmittel-Wissenschaft \& Technologie, 41: 10671072.

Chiheb I, Riadi H, Martine -Lopez J, Dominguez-Seglar JF, Gomez Vidal JA, Bouziane H, Kadiri M. 2009. Screening of antibacterial activity in marine green and brown macroalgae from the coast of Morocco. African Journal of Biotechnology, 8: $1258-1562$.

CLSI. (2008). Reference Method for Broth Dilution Antifungal Susceptibility Testing of Yeasts; Approved Standard-Third Edition. CLSI document M27-A3. In. Wayne, PA: Clinical and Laboratory Standards Institute.

CLSI. (2018). Methods for Dilution Antimicrobial Susceptibility Tests for Bacteria That Grow Aerobically-11th edition. CLSI standard M07. In. Wayne, PA: Clinical and Laboratory Standards Institute.

Dayong S, Jing L, Shuju G, Lijun H. 2008. Antithrombotic effect of bromophenol, the alga- derived thrombin inhibitor. Journal of Biotechnology, 136: 763-769.

De Felicio R, De Albuquerque S, Young MCM, Yokoya NS, Debonsi HM. 2010. Trypanocidal, leishmanicidal and antifungal potential from marine red alga Bostrychia tenella, J.Agardh (Rhodomelaceae, Ceramiales). Journal of Pharmaceutical and Biomedical Analysis, 52: 763-769.

Demirel Z, Yilmaz-Koz FF, Karabay-Yavasoglu U, Ozdemir G, Sukatar A. 2009. Antimicrobial and Antioxidant Activity of Brown Algae from the Aegean Sea. Journal of the Serbian Chemical Society, 74: 619-628.
Devi GK, Manivannan K, Thirumaran G, Rajathi FAA, Anantharaman P. 2011. In vitro antioxidant activities of selected Seaweeds from southeast coast of India. Asian Pacific Journal of Tropical Medicine, 4: 205-211.

Dulger B, Hacioglu N, Erdugan H, Aysel H. 2009. Antimicrobial Activity of Some Brown Algae from Turkey. Asian Journal of Chemistry. 21 (5): 4113-4117.

El-Baky HHA, El-Baz FK, El-Baroty GS. 2009. Natural preservative ingredient from marine alga Ulva lactuca L. International Journal of Food Science and Technology, 44(9): 1688-1695.

El-Sheekh MM, Mousa ASH, Farghl AAM. 2020. Antibacterial efficacy and phytochemical characterization of some marine brown algal extracts from the red sea, Egypt. Rom Biotechnol Lett. 25(1): 1160-1169. DOI: 10.25083/rb1/25.1/1160.1169

Erdoğan Eliuz EA, Börekçi N, Ayas D. 2019. The Antimicrobial Activity of Enteromorpha sp. Methanolic Extract and Gelatin Film Solution Against on Some Pathogens. Marine Science and Technology Bulletin, 8(2): 58-63.

Ertürk Ö, Taş B. 2011. Antibacterial and Antifungal Effects of Some Marine Algae. Kafkas Üniversitesi Veteriner Fakültesi Dergisi, 17, 121-124.

Febles CI, Arias A, Hardisson A, Sierra Lopez A. 1995. Antimicrobial Activity of Extracts from some Canary Species of Phaeophyta and Chlorophyta. Phytotherapy Research, 9: 385-387.

Glombitza KW. 1979. Antibiotics from algae. Hoppe I.L.A., Ed., Marine Algae in Pharmaceutical Science, Waiter de Gruyter, Berlin, New York, 303f.

Gümüş B, Ünlüsayın M, Gümüş E. 2018. A review on antimicrobial properties of marine macroalgae extracts. Ege Journal of Fisheries and Aquatic Sciences, 35(3): 343-351. DOI:10.12714/egejfas.2018.35.3.15

Güner A, Nalbantsoy A, Sukatar A, Karabay Yavaşoğlu, NÜ. 2019. Apoptosis-inducing activities of Halopteris scoparia L. Sauvageau (Brown algae) on cancer cells and its biosafety and antioxidant properties. Cytotechnology, 71: 687-704. Harder R. 1917. Ernahrungphysiologische untersuchughen an Cyanophyceen, Hauptsachlich am endophytischen Nostoc punctiformie. Zeitschrift für Botanik, 9: 145.

Hernandes C, Coppede JDS, Bertoni BW, França SDC, Pereira AMS. 2013. Flash microbiocide: A rapid and economic method for determination of MBC and MFC. Am. J. Plant Sci., 4: 850-852. DOI: 10.4236/ajps.2013.44104.

Kandhasamy M, Arunachalam KD. 2008. Evaluation of in vitro antibacterial property of seaweeds of southeast coast of India. African Journal of Biotechnology, 7(12): 1958-1961. DOI: 10.5897/AJB08.120

Karthikaidevi G, Manivannan K, Thirumaran G, Anantharaman P, Balasubaramanian T. 2009. Antibacterial Properties of Selected Green Seaweeds from Vedalai Coastal Waters; Gulf of Mannar Marine Biosphere Reserve Global J. Pharmacol., 3(2): 107-112.

Kim SK, Thomas NV, LI X. 2011. Anticancer compounds from marine macroalgae and their application as medicinal foods. Advanced Food and Nutrition Research, 64: 213-224.

Kuda T, Taniguchi E, Nishizawa M, Araki Y. 2002. Fate of watersoluble polysaccharides in dried Chorda filum a brown alga during water washing. Journal of Food Composition and Analysis, 15: 3-9.

Lambert RJW, Skandamis PN, Coote PJ, Nychas GJE. 2001. A study of the minimum inhibitory concentration and mode of action of oregano essential oil, thymol and carvacrol. J. Applied Microbiol., 91, 453-462. PMID: 11556910.

Martins RM, Nedel F, Guimarães VBS, da Silva AF, Colepicolo P, Pereira CMP, Lund RG. 2018. Macroalgae extracts from Antarctica have antimicrobial and anticancer potential. Front. Microbiol. 9,412. doi: 10.3389/fmicb.2018.00412 
Mohammed FS, Akgul H, Sevindik M, Khaled BMT. 2018. Phenolic content and biological activities of Rhus coriaria var. zebaria. Fresenius Environmental Bulletin, 27(8): 56945702.

Mohammed FS, Günal S, Pehlivan M, Doğan M, Sevindik M, Akgül H. 2020. Phenolic Content, Antioxidant and Antimicrobial Potential of Endemic Ferulago platycarpa. Gazi University Journal of Science, 33(4): 670-677.

Moshfegh A, Salehzadeh A, Sadat Shandiz SA. Shafaghi M, Naeemi AS, Salehi S. 2019. Phytochemical Analysis, Antioxidant, Anticancer and Antibacterial Properties of the Caspian Sea Red Macroalgae, Laurencia caspica. Iran J Sci Technol Trans Sci 43: 49-56.

Na HJ, Moon PD, Lee HJ, Kim, HR, Chae, HJ, Shin T, Seo Y, Hong SH, Kim HM. 2005. Regulatory effect of atopic allergic reaction by Corpopelt is affinis. Journal of Ethnopharmocology, 101: 43-48.

Nagayama K, Iwamura Y, Shibata T, Hirayama I. Nakamura T. 2002. Bactericidal activity of phlorotannins from the brown alga Ecklonia kurome. A review on antimicrobial properties of marine macroalgae extracts 351 Journal of Antimicrobiology Chemother, 50(6): 889-893. DOI: $10.1093 / \mathrm{jac} / \mathrm{dkf} 222$

Parsaeiemhr A, Lutzu GA. 2016. Algae as a novel source of antimicrobial compounds: Current and future perspective. In: Antibiotic Resistance. Mechanisms and New Antimicrobial Approaches - 1st edition, Eds: K. Kon, M. Rai. Academic Press.

Paul VJ, Puglisi MP. 2004. Chemical mediation of interactions among marine organisms. Natural Product Reports, 21: 189209.

Pesando D. 1990. Antibacterial and antifungal activities of marine algae. In: Introduction to Applied Phycology (I. Akatsuka, ed.). SPB Academic Publishing bv, TheHague. pp. 3-27.

Salem WM, Galal H, Nasr El-Deen F. 2011. Screening for antibacterial activities in some marine algae from the red sea (Hurghada, Egypt). African Journal of Microbiology Research, 5(15): 2160-2167. DOI: 10.5897/AJMR11.390

Salvador N, Garreta AG, Lavelli L. Riberia MA. 2007. Antimicrobial activity of Iberian macroalgae. Scientia Marina, 71 (1): 101-113.
Sevindik M, Akgul H, Pehlivan M, Selamoglu Z. 2017. Determination of therapeutic potential of Mentha longifolia ssp. longifolia. Fresen Environ Bull, 26(7): 4757-4763.

Sevindik M. 2020. Antioxidant and antimicrobial capacity of Lactifluus rugatus and its antiproliferative activity on A549 cells. Indian Journal of Traditional Knowledge (IJTK), 19(2): 423-427.

Srikong W, Bovornreungroj N, Mittraparparthorn P, Bovornreungroj P. 2017. Antibacterial and antioxidant activities of differential solvent extractions from the green seaweed Ulva intestinalis. ScienceAsia, 43: 88- 95. DOI: 10.2306/scienceasia1513-1874.2017.43.088

Stirk WA, Reinecke DL, Van Staden J. 2007. Seasonal variation in antifungal, antibacterial and acetylcholinesterase activity in seven South African seaweeds. Journal of Applied Phycology, 19(3): 271-276. DOI: 10.1007/s10811-006-9134-7

Tuney I, Cadirci BH, Unal D, Sukatar A. 2006. Antimicrobial activities of the extracts of marine algae from the coast of Urla (Izmir Turkey). Turkish Journal of Biology, 30: 171-175.

Vairappan CS, Suzuki M, Abe T, Masuda M. 2001. Halogenated metabolites with antibacterial activity of the Okinawan Laurencia species. Phyrochemistry, 58: 517-523.

Veeramohan DrR, Adaikala RG, Venkatesalu V. 2017. Antibacterial activity of methanol crude extracts of marine macroalgae from the Thikkodi Calicut west coast of India. International Journal of Pharma and Bio Sciences, 8(1):136142.

Venugopa AKB, Thirumalairaj VK, Durairaj G, Vijayan MP, Lazar N, Kurumboor Sathyan K, Chacko A, Yesudas R, Kadheeja S, David IKJ, Damascene SJ. 2014. Microbicidal activity of crude extracts from Sargassum wightii against Bacillus cereus. International Current Pharmaceutical Journal, 3(10): 326-327.

Wang C, Lu Y. Cao, S. 2020. Antimicrobial compounds from marine actinomycetes. Arch. Pharm. Res. 43: 677-704 (2020). https://doi.org/10.1007/s12272-020-01251-0

Watson SB, Cruz-Rivera E. 2003. Algal chemical ecology: an introduction to the special issue. Phycologia, 42, 319-323.

Yuan YV, Carrington MF, Walsh NA. 2005. Extracts from dulse (Palmaria palmata) are effective antioxidants and inhibitors of cell proliferation in vitro. Food and Chemical Toxicology, 43: 1073-1081. 